National and Global Petroleum Assessment

\title{
Stratigraphic Cross Sections of the Mowry Shale and Associated Strata in the Wind River Basin, Wyoming
}

By Thomas M. Finn

Pamphlet to accompany

Scientific Investigations Map 3476 


\section{U.S. Geological Survey, Reston, Virginia: 2021}

For more information on the USGS - the Federal source for science about the Earth, its natural and living resources, natural hazards, and the environment—visit https://www.usgs.gov or call 1-888-ASK-USGS.

For an overview of USGS information products, including maps, imagery, and publications, visit https://store.usgs.gov/.

Any use of trade, firm, or product names is for descriptive purposes only and does not imply endorsement by the U.S. Government.

Although this information product, for the most part, is in the public domain, it also may contain copyrighted materials as noted in the text. Permission to reproduce copyrighted items must be secured from the copyright owner.

Suggested citation:

Finn, T.M., 2021, Stratigraphic cross sections of the Mowry Shale and associated strata in the Wind River Basin, Wyoming: U.S. Geological Survey Scientific Investigations Map 3476, 1 sheet,14-p. pamphlet, https://doi.org/10.3133/sim3476.

Associated data for this publication:

Finn, T.M., 2021, Tops file for the Mowry Shale and associated strata in the Wind River Basin, Wyoming: U.S. Geological Survey data release, https://doi.org/10.5066/P9Y7SLB6.

ISSN 2329-132X (online) 


\section{Contents}

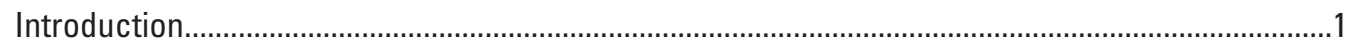

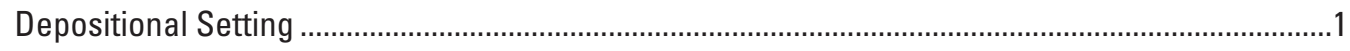

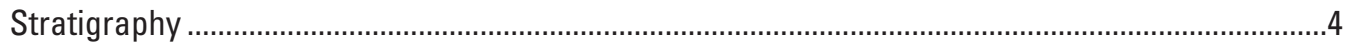

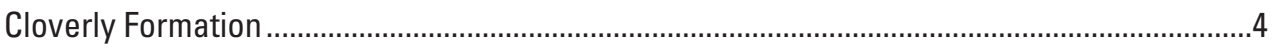

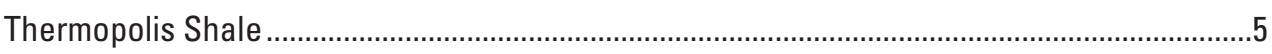

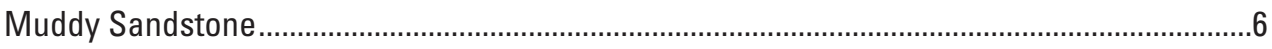

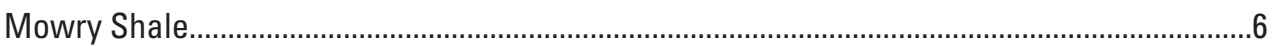

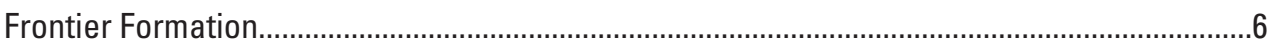

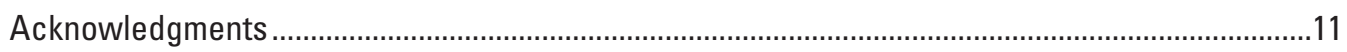

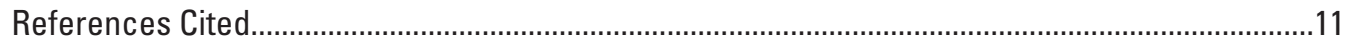

\section{Figures}

1. Map of the Rocky Mountain region showing locations of Laramide basins .....................2

2. Index map of the Wind River Basin .........................................................................................

3. Correlation chart of Lower and lowermost Upper Cretaceous rocks in the Wind River Basin ...........................................................................................................................

4. Type log of Lower and lowermost Upper Cretaceous rocks in the southeastern part of the Wind River Basin ............................................................................................

5. Map showing approximate extent of the Mowry Sea (Western Interior Seaway) in North America during early Cenomanian...........................................................................

6. Isopach map of the Mowry Shale in the Wind River Basin..............................................8

7. Isopach map of the Shell Creek Shale equivalent strata ......................................................9

8. Isopach map of the upper siliceous part of the Mowry Shale ............................................10 


\section{Conversion Factors}

U.S. customary units to International System of Units

\begin{tabular}{|c|c|c|}
\hline Multiply & By & To obtain \\
\hline \multicolumn{3}{|c|}{ Length } \\
\hline inch (in.) & 2.54 & centimeter $(\mathrm{cm})$ \\
\hline inch (in.) & 25.4 & millimeter $(\mathrm{mm})$ \\
\hline foot $(\mathrm{ft})$ & 0.3048 & meter $(\mathrm{m})$ \\
\hline mile (mi) & 1.609 & kilometer $(\mathrm{km})$ \\
\hline \multicolumn{3}{|c|}{ Area } \\
\hline square mile $\left(\mathrm{mi}^{2}\right)$ & 2.590 & square kilometer $\left(\mathrm{km}^{2}\right)$ \\
\hline
\end{tabular}

International System of Units to U.S. customary units

\begin{tabular}{lll}
\hline \multicolumn{1}{c}{ Multiply } & By & \multicolumn{1}{c}{ To obtain } \\
\hline & Length & \\
\hline centimeter $(\mathrm{cm})$ & 0.3937 & inch (in.) \\
millimeter $(\mathrm{mm})$ & 0.03937 & inch (in.) \\
meter $(\mathrm{m})$ & 3.281 & foot (ft) \\
kilometer $(\mathrm{km})$ & 0.6214 & mile (mi) \\
\hline & Area & \\
\hline square kilometer $\left(\mathrm{km}^{2}\right)$ & 0.3861 & square mile $\left(\mathrm{mi}^{2}\right)$ \\
\hline
\end{tabular}




\title{
Stratigraphic Cross Sections of the Mowry Shale and Associated Strata in the Wind River Basin, Wyoming
}

\author{
By Thomas M. Finn
}

\section{Introduction}

The Wind River Basin is a large northwest-trending structural and sedimentary basin that formed in the Rocky Mountain foreland during the Laramide orogeny in latest Cretaceous through early Eocene. The basin encompasses about 7,400 square miles $\left(\mathrm{mi}^{2}\right)$ in central Wyoming and is bounded by the Washakie, Owl Creek, and Bighorn uplifts on the north, the Casper arch on the east, the Granite Mountains uplift on the south, and the Wind River uplift on the west (fig. 1).

The first commercial oil well completed in the Wind River Basin was drilled near an oil seep in 1884 at Dallas Dome about 8 miles (mi) southeast of the present-day town of Lander (fig. 2) (Biggs and Espach, 1960). Since then, many important conventional and unconventional oil and gas resources have been discovered and produced from reservoirs ranging in age from Mississippian through Tertiary (fig. 2) (Keefer, 1969; Fox and Dolton, 1989, 1996; De Bruin, 1993; Johnson and others, 1996, 2007). It has been suggested that the Mowry Shale is an important source rock for many of these accumulations (Geis, 1923; Schrayer and Zarrella, 1963, 1966, 1968; Nixon, 1973; Burtner and Warner, 1984; Meissner and others, 1984; Davis and others, 1989; Surdam and others, 2010). With recent technological advances and success in horizontal drilling and multistage fracture stimulation, the Mowry Shale is considered an important continuous (unconventional) shale oil and shale gas objective in other Rocky Mountain basins (Sterling and others, 2009; Surdam and others, 2010; Sterling, 2013; Sterling and Grau, 2014; Finley, 2017).

The stratigraphic cross sections presented in this report were constructed as part of a project carried out by the U.S. Geological Survey (USGS) to characterize and evaluate the undiscovered continuous (unconventional) oil and gas resources of the Mowry Shale in the Wind River Basin. The purpose of the cross sections is to show the stratigraphic relationship of the Mowry Shale and associated Lower and lowermost Upper Cretaceous strata.

Two cross sections were constructed using (1) borehole geophysical logs from 41 wells drilled for oil and gas exploration and production and (2) one research well that was cored and logged by the USGS in the southeastern part of the basin (Kirschbaum and others, 2019). Both lines originate at Sheldon Dome in the northwestern part of the basin and end near Bates Creek in the extreme southeastern part of the basin (fig. 2, and map sheet). The northern line extends from Sheldon Dome east along the northern margin of the basin to Madden anticline, then southeast to Tepee Flats and Hells Half Acre, then along the southwest margin of the Casper arch to Bates Creek (fig. 2 and map sheet). The southern line extends from Sheldon Dome southeast to Riverton Dome and along the southern margin of the basin, then southeast along the northeast margin of the Rattlesnake Hills to Bates Creek (fig. 2 and map sheet). The stratigraphic interval extends from the uppermost part of the Upper Jurassic Morrison Formation to the basal part of the Upper Cretaceous Frontier Formation (fig. 3). The datum is the Clay Spur Bentonite Bed, a distinctive bed at the top of the Upper Cretaceous Mowry Shale. This datum was selected because it is easily identified on most well logs and is present throughout the basin (fig. 4 and map sheet) (Finn, 2021).

\section{Depositional Setting}

During the Late Jurassic and Cretaceous, the part of Wyoming that is now the Wind River Basin was located in the Western Interior Basin, an elongate north-south foreland basin, that developed to the east of the tectonically active Cordilleran highlands of western North America (DeCelles, 2004). From the Albian to Maastrichtian (latest Early Cretaceous to Late Cretaceous), the foreland basin was periodically flooded by the Western Interior Seaway (WIS), a broad epicontinental sea that developed in response to foreland basin subsidence and eustatic sea-level fluctuations (Steidtmann, 1993). At its maximum extent, the WIS extended for more than 3,000 mi from the Arctic Ocean to the Gulf of Mexico (Kauffman, 1977). Kauffman and Caldwell (1993) identified nine second-order transgressive-regressive marine cycles for the Cretaceous. The most widespread cycle was the Greenhorn Cycle during the Cenomanian and Turonian. The Mowry Shale was deposited during the initial stages of the Greenhorn transgression 


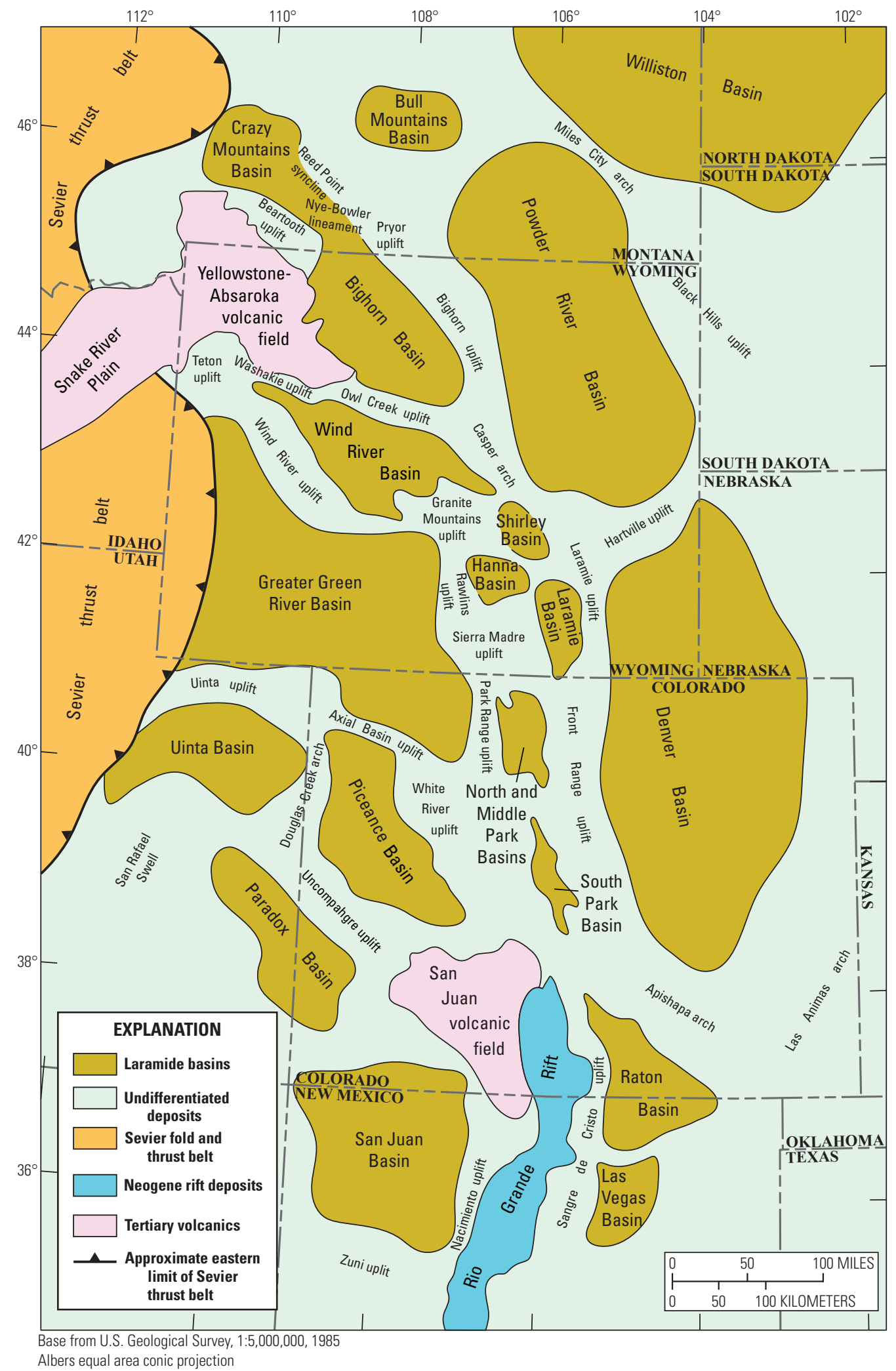

Figure 1. Map of the Rocky Mountain region showing locations of Laramide basins. 


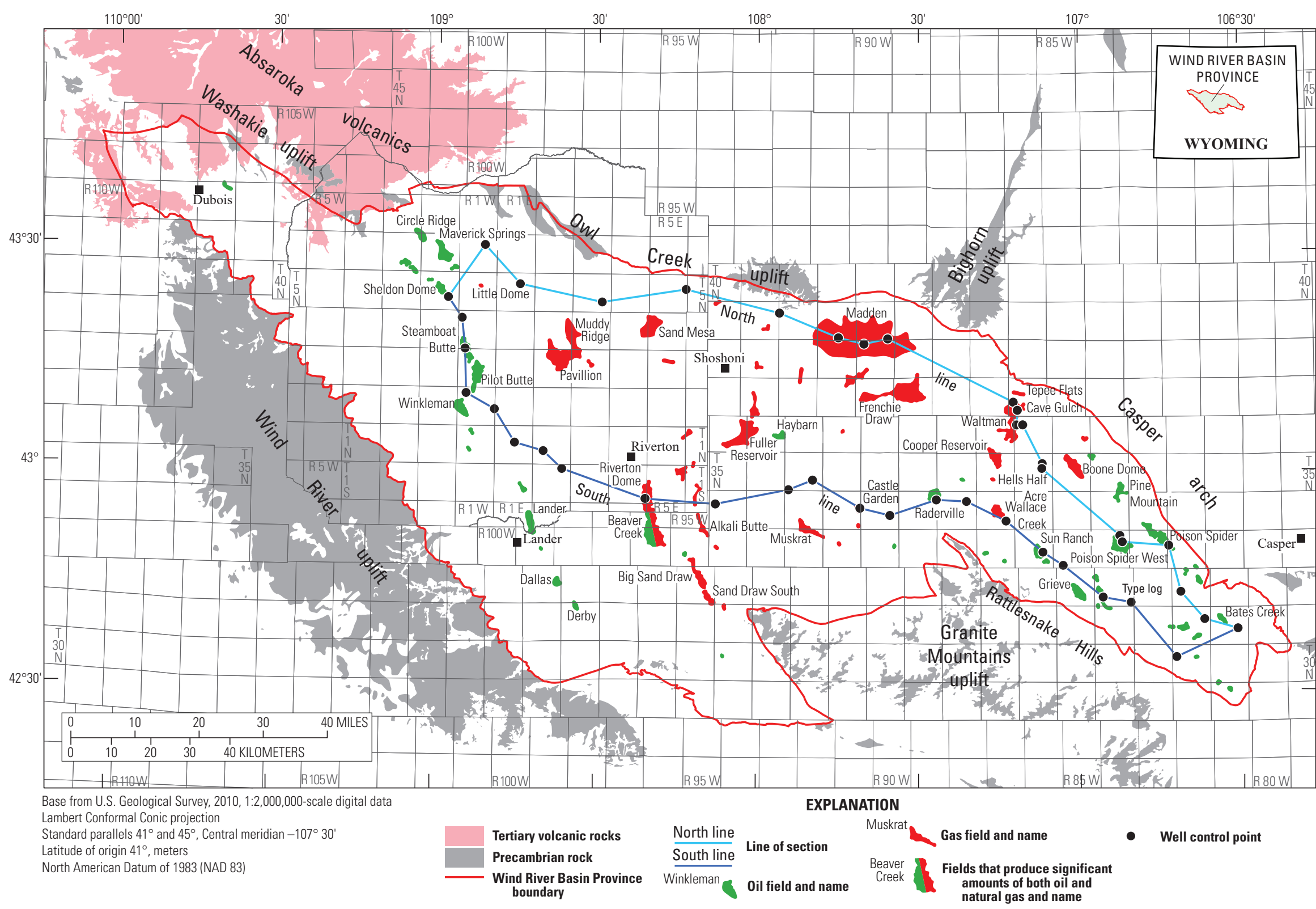

Figure 2. Index map of the Wind River Basin showing major structural elements, principal oil and gas producing fields, and cross section lines shown on map sheet. 


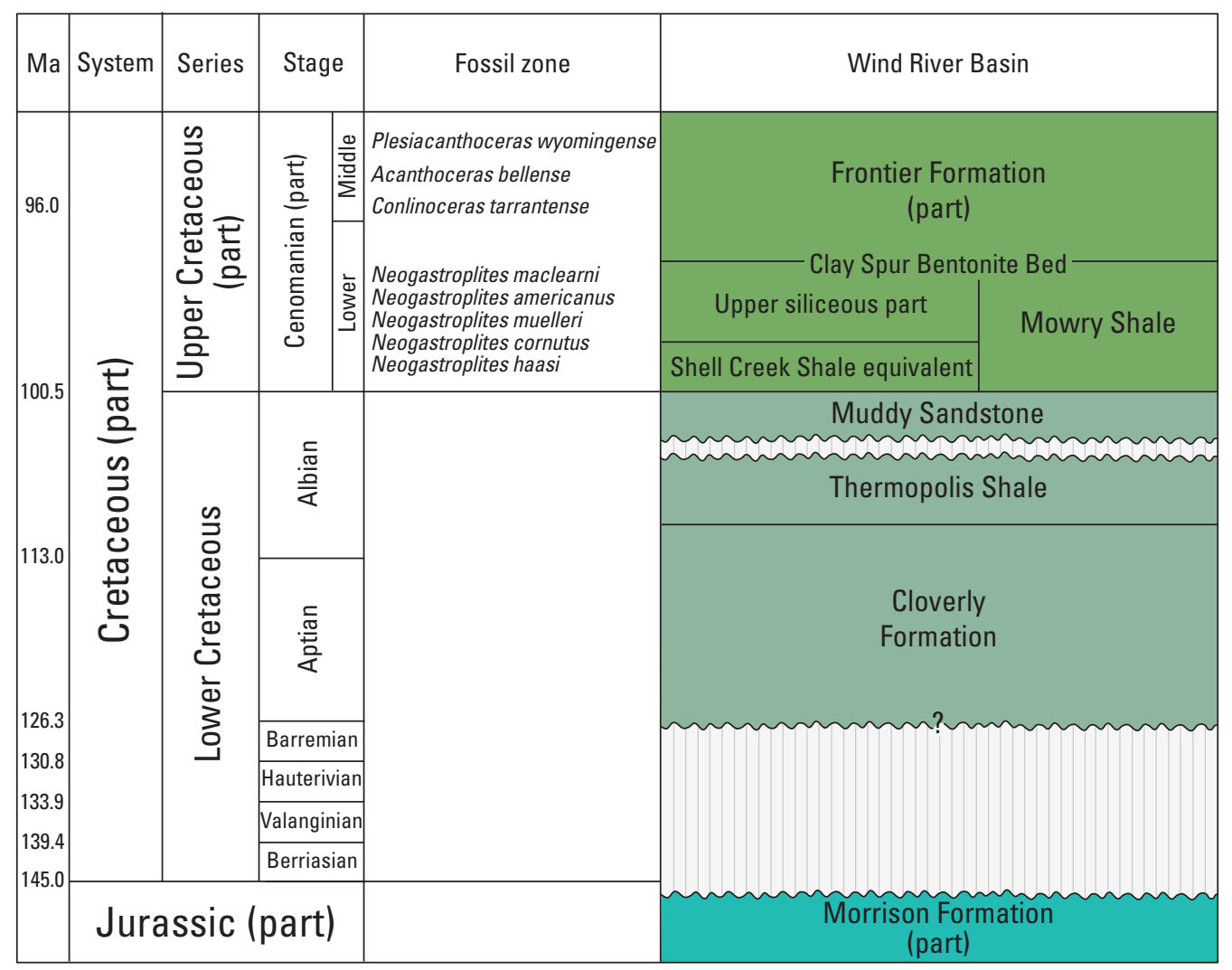

Figure 3. Correlation chart of Lower and lowermost Upper Cretaceous rocks in the Wind River Basin. Compiled from Keefer (1972), Merewether and others (1997), Cobban and others (2006), Gradstein and others (2012), Merewether and McKinney (2015), Walaszczyk and Cobban (2016), and Lynds and Slattery (2017).

in early Cenomanian when the northern arm of the WIS (often referred to as the Mowry Sea) flooded southward to the Transcontinental arch, which acted as a barrier separating the Mowry Sea from the proto-Gulf of Mexico to the south (fig. 5) (Kauffman and Caldwell, 1993; Steidtmann, 1993). Erosion of the Cordilleran highlands supplied coarser grained silicilastic sediment to the margins of the basin by eastward-flowing streams, while finer grained marine mudrocks and shale accumulated in the offshore areas (Molenaar and Rice, 1988; Roberts and Kirschbaum, 1995). Continued sea level rise of the Mowry Sea breached the Transcontinental arch connecting it with the proto-Gulf of Mexico to form the Greenhorn Sea, which reached the highest eustatic sea level of the Cretaceous by early Turonian (Kauffman and Caldwell, 1993; Roberts and Kirschbaum, 1995; Blakey, 2014).

\section{Stratigraphy}

\section{Cloverly Formation}

The basal Cretaceous rocks in the Wind River Basin are represented by the Cloverly Formation, which consist of 60-225 feet ( $\mathrm{ft}$ ) of interbedded sandstone, variegated shale, and conglomerate that unconformably overlie the Upper Jurassic Morrison Formation. The sandstones and conglomerates were deposited in fluvial systems that flowed east-northeast from the fold belt across the basin, and the shales accumulated as overbank and lacustrine deposits (May, 1992; Steidtmann, 1993; May and others, 1995). According to May (1992), the Cloverly is Aptian in age; however, Merewether and others (1997) suggest that it is in part Albian. 


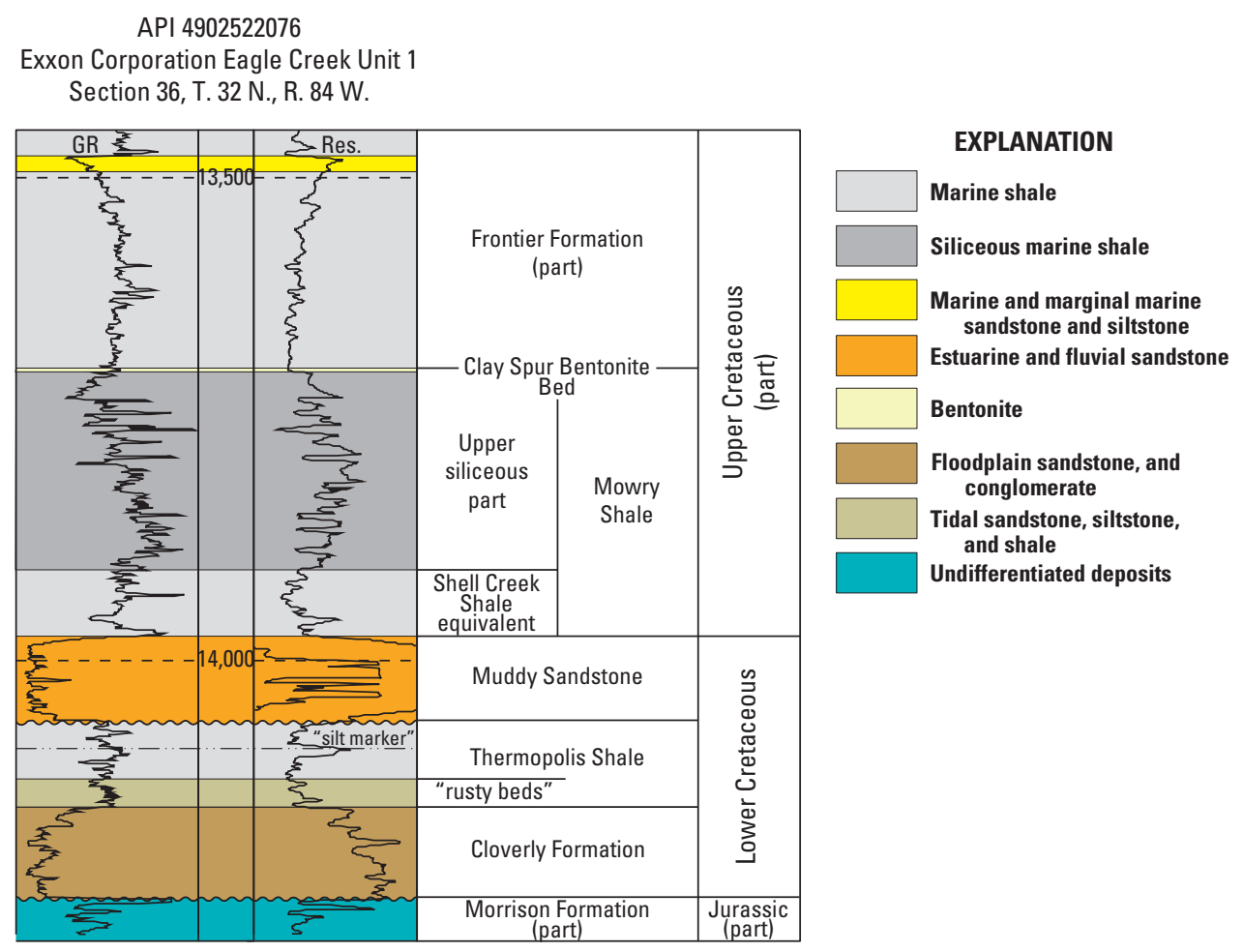

Figure 4. Type log of Lower and lowermost Upper Cretaceous rocks in the southeastern part of the Wind River Basin, GR, gamma ray log; Res., resistivity log. Location shown on figure 2.

\section{Thermopolis Shale}

The Lower Cretaceous Thermopolis Shale consists of gray to very dark gray shale, very fine grained sandstone, and siltstone (Burtner and Warner, 1984; Kirschbaum and others, 2019). It was named by Lupton (1916) for exposures near the town of Thermopolis in the southern part of the Bighorn Basin where he recognized a lower shale unit, a middle "muddy sandstone unit" and an upper shale unit. In the Wind River Basin, Love (1948) renamed Lupton's (1916) lower shale the Thermopolis Shale, the middle "muddy sandstone unit" the Muddy Sandstone and included the upper shale unit with the overlying Mowry Shale. This report uses Love's (1948) nomenclature. A distinctive high-resistivity zone or peak near the middle of the Thermopolis Shale is informally referred to as the "Dakota silt" or "silt marker" by Mitchell (1978),
Keefer (1997), and Keefer and Johnson (1997) (fig. 4 and map sheet). The basal part of the Thermopolis Shale, informally referred to as the "rusty beds" by Washburne (1908) and Eicher (1962), consists of interbedded shale, bioturbated siltstones, and very fine grained sandstones (May, 1992; Kirschbaum and others, 2019). These units accumulated in tidal flats and represent the initial transgression of the Cretaceous sea during the Albian (May, 1992). While most authors consider the "rusty beds" the basal part of the Thermopolis Shale (Washburne, 1908; Burk, 1956; Eicher, 1960, 1962; Mirsky, 1962; May 1992; May and others 1995), Love (1948) and Keefer and Troyer (1964) included the "rusty beds" with the underlying Cloverly Formation. The Thermopolis Shale, including the "rusty beds," ranges in thickness from 90 to about $220 \mathrm{ft}$. 


\section{Muddy Sandstone}

The name Muddy was first used informally by drillers for "muddy sandstones" in the lower part of the Benton Shale as described in Hintze (1915) and was referred to as the Muddy Sandstone in the Wind River Basin by Love (1948). The Lower Cretaceous Muddy Sandstone is composed of fine- to coarse-grained sandstone with interbedded shales deposited in fluvial, marginal marine, and estuarine environments (Dresser, 1974; Curry, 1985; Kirschbaum and others, 2019). The Muddy Sandstone ranges in thickness from near zero (Love, 1948) to about $100 \mathrm{ft}$, with the thickest accumulations associated with incised valley systems that developed on the exposed surface of the Thermopolis Shale during sea level lowstand (Van Wagoner and others, 1990; Dolson and others, 1991). The age of the Muddy Sandstone is Early Cretaceous, based on the presence of Albian foraminifera and ammonites in adjacent units (Eicher, 1962).

\section{Mowry Shale}

The Upper Cretaceous Mowry Shale was named by Darton (1904) for exposures of ridge-forming fossiliferous strata in the northwestern part of the Powder River Basin, and the upper contact was defined as the top of the Clay Spur Bentonite Bed (Ruby, 1930; Nixon, 1973). In the Wind River Basin, the Mowry Shale extends from the top of the Clay Spur Bentonite Bed down to the top of the Muddy Sandstone (figs. 3, 4, and map sheet). The Mowry Shale consists of a lower soft clay-rich shale (originally the upper Thermopolis shale unit of Lupton, 1916) and an upper hard siliceous unit (Keefer and Troyer, 1964; Keefer, 1997). The combined thickness of the lower and upper units ranges from less than 250 $\mathrm{ft}$ in the southeastern part of the basin to greater than $625 \mathrm{ft}$ in the northwestern part (fig. 6). This east to west increase in thickness reflects an increase in sediment supply from the tectonically active Cordilleran highlands to the west (Burtner and Warner, 1984). Both units contain abundant fish scales, bone, and Inoceramus fragments. Numerous bentonite beds in both the upper siliceous unit and lower shaley unit were derived from volcanic source areas to the west and can be traced in the subsurface throughout the basin (map sheet). The bentonite beds range in thickness from a fraction of an inch to several feet (Byers and Larson, 1979; Kirschbaum and others, 2019).

Eicher $(1960,1962)$ named the lower part of the Mowry Shale the Shell Creek Shale for exposures in the Bighorn Basin and traced it into several localities in the Wind River Basin. The Shell Creek Shale equivalent strata in the Wind
River Basin consists of medium- to dark-gray mudrock, siltstone, very fine grained sandstone, and bentonite (Love, 1948; Keefer, 1997; Kirschbaum and others, 2019) and ranges in thickness from less than $50 \mathrm{ft}$ in the southeastern part of the basin to about $180 \mathrm{ft}$ in the northwestern part (fig. 7).

The upper siliceous part of the Mowry Shale consists of 189 to $460 \mathrm{ft}$ of gray to brown organic-rich, hard brittle siliceous mudrock, siltstone, very fine grained sandstone, and bentonite (fig. 8) (Byers and Larson, 1979; Burtner and Warner, 1984; Kirschbaum and others, 2019). To the west, the upper part of the Mowry Shale grades laterally into sandstones that have been traditionally included with the overlying Frontier Formation (Love, 1948; Keefer, 1972). These sandstones, however, occur below the Clay Spur Bentonite Bed and are included here with the upper part of the Mowry Shale (map sheet).

${ }^{40} \mathrm{Ar} / 39 \mathrm{Ar}$ dates of 98.19 and $99.25 \mathrm{Ma}$ determined on sanidine from bentonite beds in the Shell Creek equivalent strata near Maverick Springs in the northwestern part of the basin and a date of 97.17 Ma for the Clay Spur Bentonite Bed near Casper, along with the presence of ammonites from the genus Neogastroplites, indicate an early Cenomanian age for the Mowry Shale (fig. 3) (Reeside and Cobban, 1960; Obradovich, 1993; Weimer and others, 1997; Walaszczyk and Cobban, 2016).

\section{Frontier Formation}

The Upper Cretaceous Frontier Formation was named by Knight (1902) for exposures near the town of Frontier in western Wyoming, and the formation name was first used in the Wind River Basin by Hares (1916). In the Wind River Basin, the Frontier Formation consists of alternating sandstone, siltstone, shale, and bentonite that accumulated in marine and marginal marine environments (Merewether and Cobban, 2007). Sandstones are generally present in the upper part of the formation, whereas the lower part is composed of shale, except in the western part of the basin where several sandstone beds are present in the lower part. According to Merewether and Cobban (2007), the Frontier Formation is Cenomanian to Coniacian and ranges in thickness from 650 to $1,000 \mathrm{ft}$. The Frontier consists of three members, in ascending order: (1) Belle Fourche Shale Member, (2) Emigrant Gap Member, and (3) Wall Creek Sandstone Member. Only the basal part of the Frontier is shown on the cross sections where it conformably overlies the Mowry Shale (map sheet). 


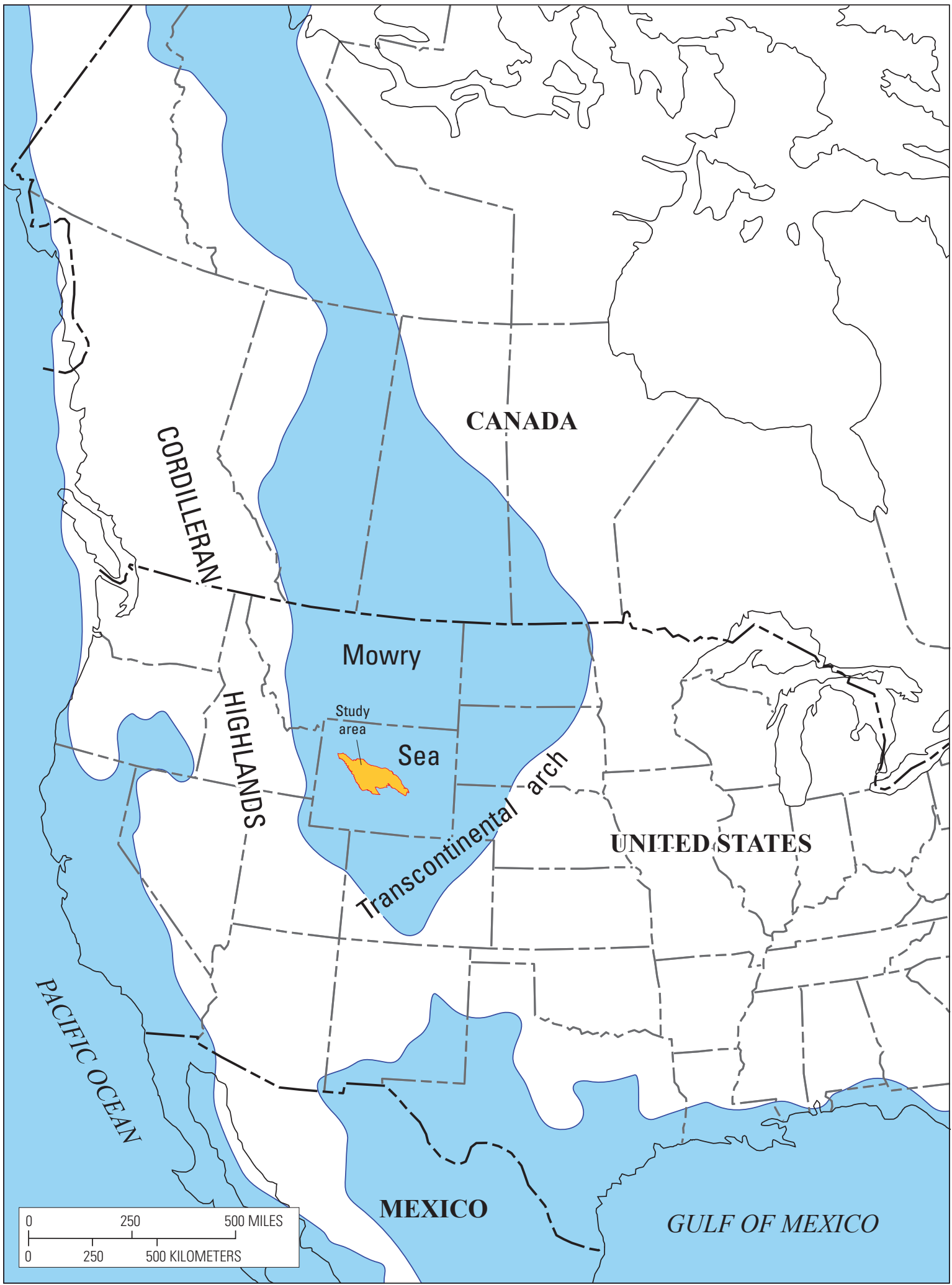

Figure 5. Map showing approximate extent of the Mowry Sea (Western Interior Seaway) in North America during early Cenomanian. Modified from Kauffman and Caldwell (1993) and Blakey (2014). 


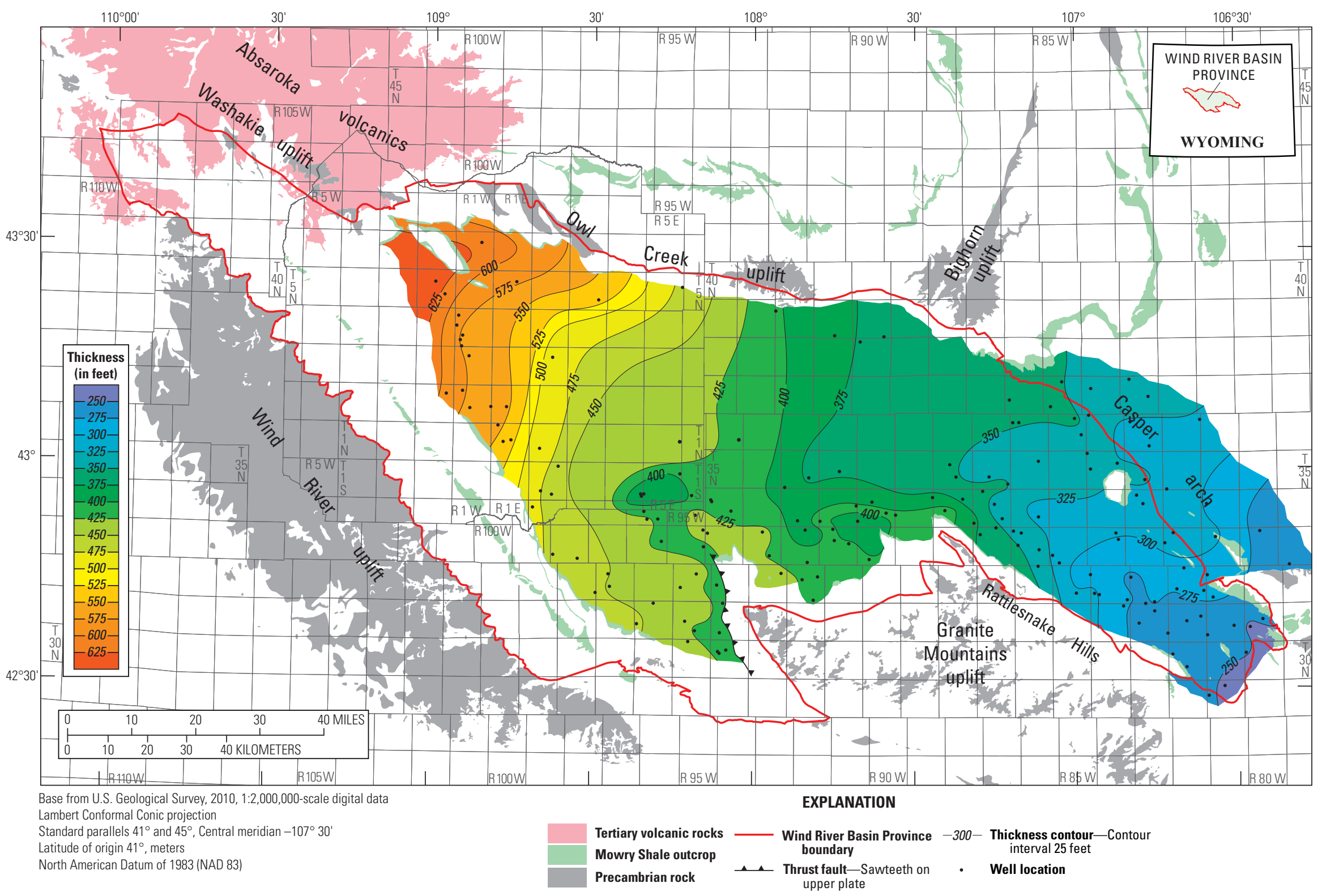

Figure 6. Isopach map of the Mowry Shale in the Wind River Basin. This map includes the interval from the top of the Clay Spur Bentonite Bed to the top of the Muddy Sandstone. Thickness interval 25 feet. 


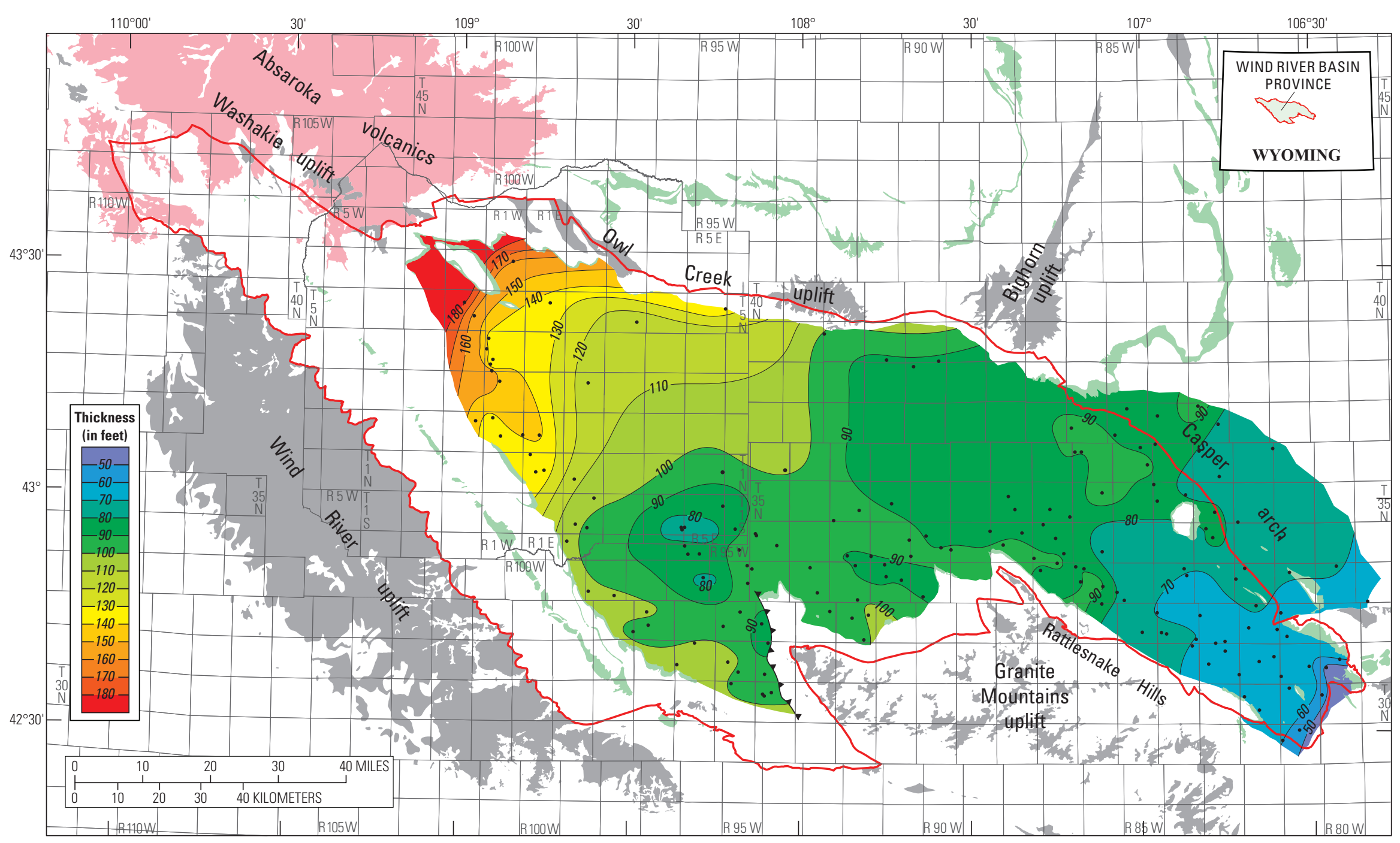

Base from U.S. Geological Survey, 2010, 1:2,000,000-scale digital data

Lambert Conformal Conic projection

Standard parallels $41^{\circ}$ and $45^{\circ}$, Central meridian $-107^{\circ} 30^{\circ}$

Latitude of origin $41^{\circ}$, meters

North American Datum of 1983 (NAD 83)

EXPLANATION 


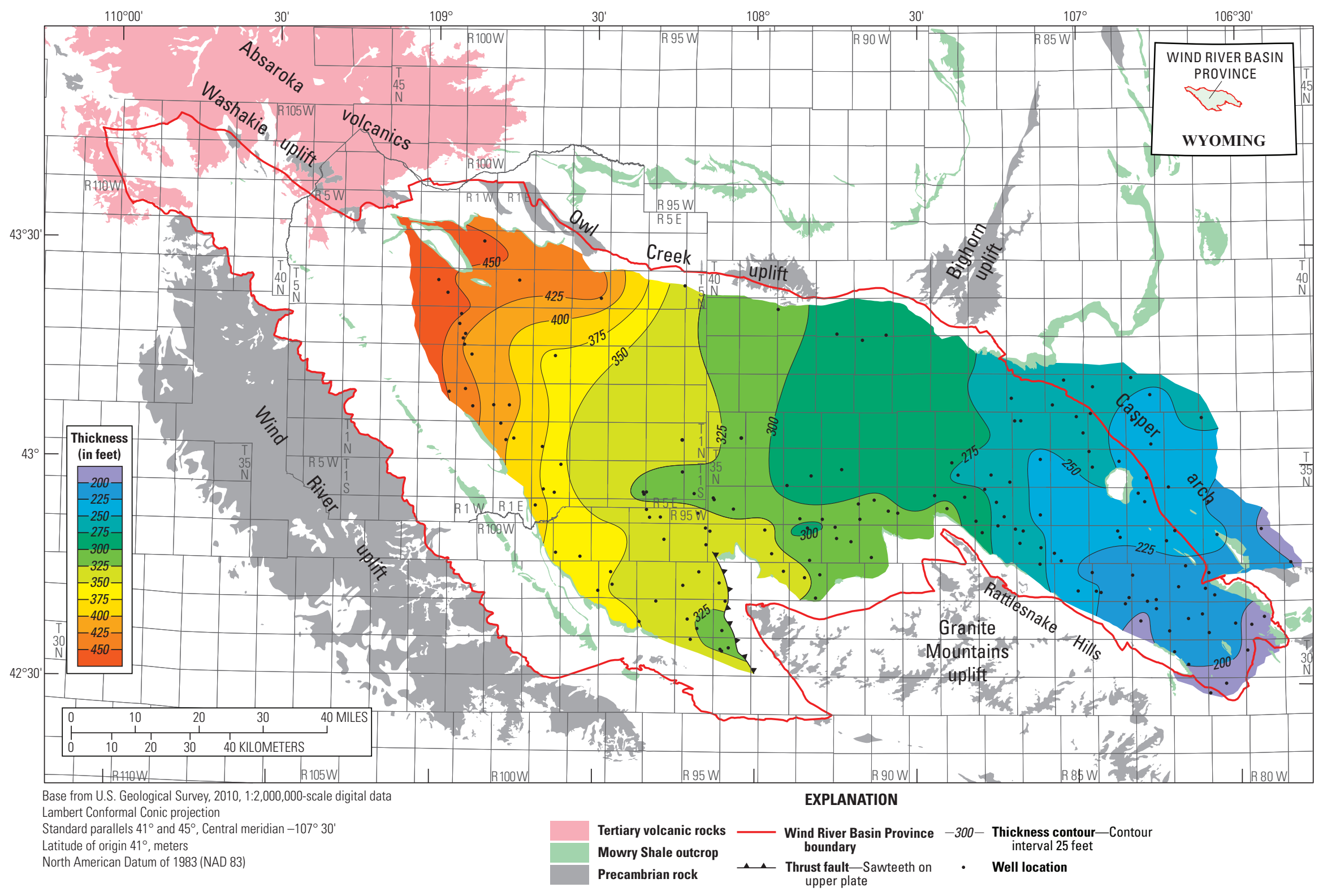

Figure 8. Isopach map of the upper siliceous part of the Mowry Shale. This map includes the interval from top of the Clay Spur Bentonite Bed to the top of the Shell Creek Shale equivalent strata. Thickness interval 25 feet. 


\section{Acknowledgments}

The report benefitted from reviews by Brian Shaffer, Ron Drake, Kristen Marra, and Ofori Pearson of the U.S. Geological Survey, and their suggestions and comments are greatly appreciated.

\section{References Cited}

Biggs, P., and Espach, R.H., 1960, Petroleum and natural gas fields in Wyoming: U.S. Bureau of Mines Bulletin 582, 538 p.

Blakey, R.C., 2014, Paleogeography and paleotectonics of the Western Interior Seaway, Jurassic, Cretaceous of North America: American Association of Petroleum Geologists, Search and Discovery Article 30392, 72 p., accessed March 17, 2020, at https://www.searchanddiscovery.com/ documents/2014/30392blakey/ndx_blakey.pdf.

Burk, C.A., 1956, Subsurface stratigraphy of the pre-Niobrara Formations in the Wind River Basin, central Wyoming, Wyoming stratigraphy, part I, Subsurface stratigraphy of pre-Niobrara Formations in Wyoming. Wyoming Geological Association, p. 23-33.

Burtner, R.L., and Warner, M.A., 1984, Hydrocarbon generation in Lower Cretaceous Mowry and Skull Creek Shales of the northern Rocky Mountain area, in Woodward, J., Meissner, F.F., and Clayton, J.L., eds., Hydrocarbon source rocks of the greater Rocky Mountain Region. Rocky Mountain Association of Geologists Guidebook, p. 449-467. [Also available at https://archives.datapages.com/data/rmag/ SourceRocks84/burtner.htm.]

Byers, C.W., and Larson, D.W., 1979, Paleoenvironments of Mowry Shale (Lower Cretaceous), western and central Wyoming: The American Association of Petroleum Geologists Bulletin, v. 63, no. 3, p. 354-361.

Cobban, W.A., Walaszczyk, I., Obradovich, J.D., and McKinney, K.C., 2006, A USGS zonal table for the Upper Cretaceous middle Cenomanian-Maastrichtian of the Western Interior of the United States based on ammonites, inoceramids, and radiometric ages: U.S. Geological Survey Open-File Report 2006-1250, 45 p. [Also available at https://doi.org/10.3133/ofr20061250.]

Curry, W.H., III, 1985, Grieve paleovalley of the Muddy Sandstone in the eastern Wind River Basin, in Nelson, G.E., ed., The Cretaceous geology of Wyoming: Wyoming Geological Association Guidebook 36th Annual Field Conference, p. 75-79.
Darton, N.H., 1904, Comparison of the stratigraphy of the Black Hills, Bighorn Mountains, and Rocky Mountain Front Range: Geological Society of America Bulletin, v. 15, no. 1, p. 379-448. [Also available at https://doi.org/10.1130/ GSAB-15-379.]

Davis, H.R., Byers, C.W., and Pratt, L.M., 1989, Depositional mechanisms and organic matter in Mowry Shale (Cretaceous), Wyoming: The American Association of Petroleum Geologists Bulletin, v. 73, no. 9, p. 1103-1116.

De Bruin, R.H., 1993, Overview of oil and gas geology of Wyoming, in Snoke, A.W., Steidtmann, J.R., and Roberts, S.M., eds., Geology of Wyoming-Geological Survey of Wyoming Memoir No. 5 p. 836-873.

DeCelles, P.G., 2004, Late Jurassic to Eocene evolution of the Cordilleran thrust belt and foreland basin system, western U.S: American Journal of Science, v. 304, no. 2, p. 105-168. [Also available at https://doi.org/10.2475/ ajs.304.2.105.]

Dolson, J., Muller, D., Evetts, M.J., and Stein, J.A., 1991, Regional paleotopographic trends and production, Muddy Sandstone (Lower Cretaceous), central and northern Rocky Mountains: The American Association of Petroleum Geologists Bulletin, v. 75, no. 3, p. 409-435. [Also available at https://doi.org/10.1306/2F0C9B27F9-1710 -11D7-8645000102C1865D.]

Dresser, H.W., 1974, Muddy Sandstone-Wind River BasinWyoming Geological Association: Earth Science Bulletin, v. 7, no. 1, p. 5-70.

Eicher, D.L., 1960, Stratigraphy and micropaleontology of the Thermopolis Shale: Peabody Museum of Natural History Yale University Bulletin 15, 126 p.

Eicher, D.L., 1962, Biostratigraphy of the Thermopolis, Muddy, and Shell Creek Formations, in Enyert, R.L., and Curry, W.H., eds., Symposium on Early Cretaceous rocks of Wyoming and adjacent areas: Wyoming Geological Association 17th Annual Field Conference Guidebook, p. 72-93.

Finley, A., 2017, Mowry Shale-Outcrop to production: Search and Discovery Article \#10917, accessed January 15, 2020 at https://www.searchanddiscovery.com/pdfz/documents/2017/ 10916finley/ndx_finley.pdf.

Finn, T.M., 2021, Tops file for the Mowry Shale and associated strata in the Wind River Basin, Wyoming: U.S. Geological Survey data release. [Also available at https://doi.org/10.5066/P9Y7SLB6.] 
Fox, J.E., and Dolton, G.L., 1989, Petroleum geology of the Wind River and Bighorn Basins, Wyoming and Montana: U.S. Geological Survey Open-File Report 87-450-P, 41 p. [Also available at https://pubs.er.usgs.gov/publication/ ofr87450P.]

Fox, J.E., and Dolton, G.L., 1996, Wind River Basin Province (35); in Gautier, D.L., Dolton, G.L., Takahashi, K.I., and Varnes, K.L., eds., 1995 National assessment of United States oil and gas resources-results, methodology, and supporting data: U.S. Geological Survey Digital Data Series DDS-30, release 2. [Also available at https://doi.org/10.3133/ds30.]

Geis, W.H., 1923, The origin of light oils in the Rocky Mountain region: The American Association of Petroleum Geologists Bulletin, v. 7, no. 5, p. 488-506.

Gradstein, F.M., Ogg, J.G., Schmitz, M.D., and Ogg, G.M., 2012, The geologic time scale 2012: Elsevier Publishing Company, 1,144 p.

Hares, C.J., 1916, Anticlines in central Wyoming, in Part, I.I., ed., Mineral fuels, of Contributions to economic geology: U.S. Geological Survey Bulletin 641-I, p. 233-279. [Also available at https://doi.org/10.3133/b641I.]

Hintze, F.F., 1915, The Basin and Greybull oil and gas fields: Wyoming Geological Survey Bulletin 10, 62 p.

Johnson, R.C., Finn, T.M., Crovelli, R.A., and Balay, R.H., 1996, An assessment of in-place gas resources in low-permeability Upper Cretaceous and lower Tertiary sandstone reservoirs, Wind River Basin, Wyoming: U.S. Geological Survey Open-File Report 96-264, 67 p. [Also available at https://doi.org/10.3133/ofr96264.]

Johnson, R.C., Finn, T.M., Kirschbaum, M.A., Roberts, S.B., and Roberts, L.N.R., Cook, T., and Taylor, D.J., 2007, The Cretaceous-Lower Tertiary Composite Total Petroleum System, Wind River Basin, Wyoming, in USGS Wind River Basin Province Assessment Team, Petroleum systems and geologic assessment of oil and gas in the Wind River Basin Province, Wyoming: U.S. Geological Survey Digital Data Series DDS-69-J, ch. 4, DDS-69-J, 96 p. [Also available at https://pubs.usgs.gov/dds/dds-069/dds-069-j/.]

Kauffman, E.G., 1977, Geological and biological overviewWestern Interior Cretaceous Basin, in Kauffman, E.G., ed., Cretaceous facies, faunas, and paleoenvironments across the Western Interior Basin: The Mountain Geologist, v. 14, nos. 3 and 4, p. 75-99.

Kauffman, E.G., and Caldwell, W.G.E., 1993, The Western Interior Basin in space and time, in Caldwell, W.G.E., and Kauffman, E.G., eds., Evolution of the Western Interior Basin: Geological Association of Canada, Special Paper 39, p. 1-30.
Keefer, W.R., 1969, Geology of petroleum in the Wind River Basin, central Wyoming: The American Association of Petroleum Geologists Bulletin, v. 53, no. 9, p. 1839-1865.

Keefer, W.R., 1972, Frontier, Cody, and Mesaverde Formations in the Wind River and southern Bighorn Basins, Wyoming: U.S. Geological Survey Professional Paper 495-E, 23 p. [Also available at https://doi.org/10.3133/pp495E.]

Keefer, W.R., 1997, Stratigraphy and correlation of Cretaceous and Paleocene rocks, northern Wind River Basin, Wyoming: U.S. Geological Survey Oil and Gas Investigations Chart OC146-A. [Also available at https://doi.org/10.3133/oc146A.]

Keefer, W.R., and Johnson, R.C., 1997, Stratigraphy and correlation of Cretaceous and Paleocene rocks, west-central Wind River Basin, Wyoming: U.S. Geological Survey Oil and Gas Investigations Chart OC-146-B. [Also available at https://doi.org/10.3133/oc146B.]

Keefer, W.R., and Troyer, M.L., 1964, Geology of the Shotgun Butte area, Fremont County, Wyoming: U.S. Geological Survey Bulletin 1157, 123 p. [Also available at https://doi.org/10.3133/b1157.]

Kirschbaum, M.A., Finn T.M., Schenk, C.J., and Hawkins, S.J., 2019, Lithologic descriptions, geophysical logs, and sourcerock geochemistry of the Alcova Reservoir AR-1-13 core hole, Natrona County, Wyoming: U.S. Geological Survey Scientific Investigations Report 2019-5123, 33 p., accessed March 17, 2020, at https://doi.org/10.3133/sir20195123.

Knight, W.C., 1902, The petroleum fields of Wyoming: Engineering and Mining Journal, part III, v. 73, no. 21, p. $720-723$.

Love, J.D., 1948, Mesozoic stratigraphy of the Wind River Basin, central Wyoming, in Maebius, J.B., and Netterstrom, P.W., eds., Wind River Basin, Wyoming: Wyoming Geological Association 3rd Annual Field Conference, p. 96-111.

Lupton, C.T., 1916, Oil and gas near Basin, Big Horn County, Wyoming: U.S. Geological Survey Bulletin, v. 621, p. $157-190$.

Lynds, R.M., and Slattery, J.S., 2017, Correlation of the Upper Cretaceous strata of Wyoming: Wyoming Geological Survey Open File Report 2017-3.

May, M.T., 1992, Intra-and extra-basinal tectonism, climate and intrinsic threshold cycles as possible controls on Early Cretaceous fluvial architecture, Wind River Basin, Wyoming, in Mullen, C.E., ed., Rediscover the Rockies: Wyoming Geological Association 43rd Field Conference Guidebook, p. 61-74. 
May, M.T., Furer, L.C., Kvale, E.P., Suttner, L.J., Johnson, G.D., and Meyers, J.H., 1995, Chronostratigraphy and tectonic significance of Lower Cretaceous conglomerates in the foreland of central Wyoming, in Dorobek, S.L., and Ross, G.M., eds., Stratigraphic evolution of foreland basins-Society of Economic Paleontologists and Mineralogists Special Publication no. 52 p. 97-110. [Also available at https://doi.org/10.2110/pec.95.52.0097.]

Meissner, F.F., Woodward, J., and Clayton, J.L., 1984, Stratigraphic relationships and distribution of source rocks in the greater Rocky Mountain region, in Woodward, J., Meissner, F.F., and Clayton, J.L., eds., Hydrocarbon source rocks of the greater Rocky Mountain region. Rocky Mountain Association of Geologists Guidebook, p. 1-34.

Merewether, E.A., and Cobban, W.A., 2007, Outcrop descriptions and fossils from the Upper Cretaceous Frontier Formation, Wind River Basin and adjacent areas, Wyoming in U.S. Geological Survey Wind River Basin Assessment Team, eds., Petroleum Systems and Geologic Assessment of Oil and Gas Resources in the Wind River Basin Province, Wyoming: U.S. Geological Survey Digital Data Series DDS-69-J, chap. 11, 95 p., CD-ROM. [Also available at https://pubs.usgs.gov/dds/dds-069/dds-069-j/.]

Merewether, E.A., Dolson, J.C., Hanson, W.B., Keefer, W.R., Law, B.E., Mueller, R.E., Ryer, T.A., Smith, A.C., Stilwell, D.P., and Wheeler, D.M., 1997, Cretaceous stratigraphy in a northeast-trending transect, northern Utah to south-central South Dakota: U.S. Geological Survey Map I-2609. [Also available at https://doi.org/10.3133/i2609.]

Merewether, E.A., and McKinney, K.C., 2015, Chronostratigraphic cross section of Cretaceous formations in western Montana, western Wyoming, eastern Utah, northeastern Arizona, and northwestern New Mexico, U.S.A.: U.S. Geological Survey Open-File Report 2015-1087, 10 p., 1 sheet, accessed March 17, 2020 at https://doi.org/10.3133/ofr20151087.

Mirsky, A., 1962, Stratigraphy of non-marine Upper Jurassic and Lower Cretaceous rocks, southern Bighorn Mountains, Wyoming: The American Association of Petroleum Geologists Bulletin, v. 46, no. 9, p. 1653-1680.

Mitchell, G., 1978, Grieve oil field-A Lower Cretaceous estuarine deposit, in Boyd, R.G., Boberg, W.W, and Olsen, G.M., eds., Resources of the Wind River Basin: Wyoming Geological Association 30th Annual Field Conference Guidebook, p. 147-165.

Molenaar, C.M., and Rice, D.D., 1988, Cretaceous rocks of the Western Interior Basin, in Sloss, L.L., ed., The Geology of North America - Sedimentary cover-North American craton, U.S v. D-2: Boulder, Colo., Geological Society of America, p. 77-82. [Also available at https://doi.org/ 10.1130/DNAG-GNA-D2.77.]
Nixon, R.P., 1973, Oil source beds in Cretaceous Mowry Shale of northwestern interior United States: The American Association of Petroleum Geologists Bulletin, v. 57, no. 1, p. 136-161.

Obradovich, J.D., 1993, A Cretaceous time scale, in Caldwell, W.G.E., and Kauffman, E.G., eds., Evolution of the Western Interior Basin: Geological Association of Canada Special Paper 39, p. 379-396.

Reeside, J.B., Jr., and Cobban, W.A., 1960, Studies of the Mowry Shale (Cretaceous) and contemporary formations in the United States and Canada: U.S. Geological Survey Professional Paper 355, 126 p. [Also available at https://doi.org/10.3133/pp355.]

Roberts, L.N.R., and Kirschbaum, M.A., 1995, Paleogeography of the Late Cretaceous of the Western Interior of Middle North America - Coal distribution and sediment accumulation: U.S. Geological Survey Professional Paper 1561, 115 p. [Also available at https://doi.org/10.3133/pp1561.]

Ruby, W.W., 1930, Lithologic studies of the fine-grained Upper Cretaceous sedimentary rocks of the Black Hills region: U.S. Geological Survey Professional Paper 165, 54 p.

Schrayer, G.J., and Zarrella, W.M., 1963, Organic geochemistry of shale-I Distribution of organic matter in the siliceous Mowry Shale of Wyoming: Geochimica et Cosmochimica Acta, v. 27, no. 10, p. 1033-1046. [Also available at https://doi.org/10.1016/0016-7037(63)90064-4.]

Schrayer, G.J., and Zarrella, W.M., 1966, Organic geochemistry of shale-II Distribution of extractable organic matter in the siliceous Mowry Shale of Wyoming: Geochimica et Cosmochimica Acta, v. 30, no. 4, p. 415-434. [Also available at https://doi.org/10.1016/0016-7037(66)90070-6.]

Schrayer, G.J., and Zarrella, W.M., 1968, Organic carbon in the Mowry Formation and its relation to the occurrence of petroleum in Lower Cretaceous reservoir rocks, in Wulf, G.R., ed., Black Hills area South Dakota, Montana, Wyoming: Wyoming Geological Association 20th Field Conference Guidebook, p. 35-39.

Steidtmann, J.R., 1993, The Cretaceous foreland basin and its sedimentary record, in Snoke, A.W., Steidtmann, J.R., and Roberts, S.M., eds., Geology of Wyoming - Geological Survey of Wyoming Memior, no. 5 p. 250-271.

Sterling, R., 2013, Mowry Shale, properties and potential, Bighorn and Powder River Basins, Wyoming: AAPG Datapages/Search and Discovery Article \#90169, 2013 AAPG Rocky Mountain Section Meeting, Salt Lake City, Utah, September 22-24, 1 p., accessed March 17, 2020, at https://www.searchanddiscovery.com/abstracts/html/2013/ 90169rms/abstracts/ster.htm. 
Sterling, R., and Grau, A., 2014, From Monterey to Mowry, with many stops in between: AAPG Datapages/Search and Discovery Article \#80385, 2014 AAPG Annual Convention, Houston, Texas, April 6-9, accessed February 2, 2020, at https://www.searchanddiscovery.com/documents/2014/ 80385sterling/ndx_sterling.pdf.

Sterling, R., Silverman, M., and Stewart, G., 2009, The Mowry Shale, review of potential in the Bighorn Basin, Unconventional reservoirs - Oil and gas shales and CBM: Rocky Mountain Association of Geologists and PTTC fall symposium, $1 \mathrm{p}$.

Surdam, R.C., Jiao, Z., De Bruin, R.H., and Bentley, R.D., 2010, Shale gas potential of the Mowry Shale in Wyoming Laramide Basins: Wyoming State Geological Survey Challenges in Geologic Resource Development, no. 9, 36 p.

Van Wagoner, J.C., Mitchum, R.M., Campion, K.M., and Rahmanian, V.D., 1990, Siliciclastic sequence stratigraphy in well logs, cores, and outcrops - Concepts for high-resolution correlation of time and facies: American Association of Petroleum Geologists Methods in Exploration Series, no. 7, 55 p.

Walaszczyk, I., and Cobban, W.A., 2016, Inoceramid bivalves and biostratigraphy of the upper Albian and lower Cenomanian of the United States Western Interior Basin: Cretaceous Research, v. 59, p. 30-68. [Also available at https://doi.org/ 10.1016/j.cretres.2015.10.019.]

Washburne, C.W., 1908, Gas fields of the Bighorn Basin, Wyoming: U.S. Geological Survey Bulletin, v. 340-F, p. 348-363.

Weimer, R.J., Obradovich, J.D., Cobban, W.A., and Merewether, E.A., 1997, A time framework for the late Albian and early Cenomanian strata of northern Wyoming and Montana, in Campen, E.B., ed., Bighorn Basin50 years on the frontier: Yellowstone Bighorn Research Association-Wyoming Geological Association-Montana Geological Society, 1997 Field Trip and Symposium, p. 36.
Central Energy Resources Science Center

Publishing support provided by the Science Publishing Network, Denver Publishing Service Center

For more information concerning the research in this report, contact the Center Director, USGS Central Energy Resources Science Center

Box 25046, Mail Stop 939

Denver, CO 80225

(303) 236-1647

Or visit the Central Energy Resources Science Center website at https://www.usgs.gov/energy-and-minerals/energy-resources-program/ 



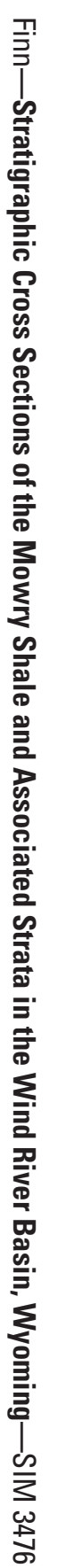

